\title{
The Political Projections of the Great Powers with Respect to Eastern Europe, 1925-1926
}

\section{Algimantas KASPARAVIČIUS}

During the mid-1920s Europe witnessed the emergence of a new political order. Exhausted by post-war confrontation, European states began an intensive search for ways of reducing conflicts, in particular between the victorious and the defeated powers, as well as strengthening their security. This endeavour culminated in the Locarno Conference of October 5-16, 1925, attended by delegations from Great Britain, France, Germany, Belgium, Italy, Czechoslovakia and Poland. As a result of the agreements reached at this small Swiss town, the revisionist tendencies of Germany in the west were blocked by the Rhine Guarantee Pact which ensured the inviolability of the German-Belgian and German-French borders. Meanwhile, Berlin refused to guarantee its eastern borders with Poland and Czechoslovakia. Great Britain, seeking Germany's more rapid integration into the economic and political structures of Europe, supported this position of Berlin ${ }^{1}$. On the other hand, London did not regard the Locarno agreement as the end of the construction of a security system in Europe, but only as the beginning, and suggested that other states should accept this system as a model. The British Foreign Secretary, Austin Chamberlain, was convinced that the Locarno system would expand, and that the easiest way to guarantee universal security was for every state to provide itself with necessary guarantees, especially in the region where its interests were focused and one of which danger was most likely to arise ${ }^{2}$.

However, the resolutions of the Locarno Conference in effect presupposed two different tendencies in European politics. First of all this was an unprecedented agreement in post-war Europe directed not against a specific aggressor but against any aggression in a particular region. The Pact managed to reduce tension considerably and created a link between countries that had quite recently been at war with one another. The Pact's main ideological objective, unlike that of previous treaties, was to avoid war rather than to guarantee security in the event of war ${ }^{3}$. On the other hand, Locarno demonstrated the

${ }^{1} \mathrm{~J}$. Korbel, Poland between East and West. Soviet and German diplomacy toward Poland 1919-1933, New Jersey, 1963, 167-168.

${ }^{2}$ V.M. Jordan, Velikobritania, Frantsia i Germanskaia problema v 1918-1938, Moscow, $1945,269$.

${ }^{3}$ Ibid., 268. 
emergence in Europe of a multilevel security system under which the states were virtually grouped into different levels. Those of the first were granted security and border inviolability, the second were abandoned in revisionist ignorance, while the security of the third was interpreted as an exclusive problem of their own. The states which had not been included in the Locarno security system, sought other ways and means to defend their interests. It divided Europe and encouraged the imperialist and revisionist stances of a number of states.

The Soviet Union's reaction to the Locarno Treaties was twofold. On the one hand, it disapproved of Germany's rapprochement with the western states. After the successful Treaty of Rapallo, 1922, and the military-political co-operation between Germany and the USSR, Moscow regarded Locarno as a significant blow which promised to spoil the protracted idyll between Russians and Germans. After Locarno the Soviets did not look at Germany with trust. Therefore, wishing to mend its political faux pas, Moscow launched its political drives towards the west. As early as on October 12, 1925 a German-Russian commercial treaty was signed in Moscow emphasizing the inviolability of the Rapallo regulations. Another insurance was taken out on April 24, 1926, when a neutrality and non-aggression pact was concluded between Germany and the USSR. On the other hand, using the exposed German revisionism and Poland's weakening international situation as well as the wish to neutralize the revisionist tendencies of Berlin ${ }^{4}$; the USSR opened negotiations with Poland in 1925 , too, over the conclusion of the political Pact. Somewhat later, the Soviets entered into political dialogue with the Baltic States over the issue of non-aggression and neutrality agreements. In this case Moscow also cherished particular and specific interests. Holding talks simultaneously with Poland and Lithuania and taking account of the unresolved Lithuanian-Polish conflict over Vilnius, Moscow drafted its expansionist plans. Therefore, despite the fact that the West set great store by the signing of the Locarno Treaties, waiting for developments in East European polities and hoping that this process would continue with an "East Locarno", the German reluctance to guarantee the Polish borders, and the USSR's aim that no any major agreement in Eastern Europe ${ }^{5}$ without Russian participation were ruining these optimistic perspectives.

On July 17, 1925 the Soviet ambassador in Lithuania Ivan Lorents was replaced by another Soviet diplomat, Sergei Aleksandrovsky ${ }^{6}$. It has to be noted that on the very first day of his

${ }^{4}$ E. Czapiewski, Koncepcje polityki zagranicznej konserwatorystów polskich w latach 1918-1926, Wrocław, 1988, 168.

${ }^{5}$ A.E. Senn, The Great Powers: Lithuania and the Vilna Question 1920-1928, Leiden, 1966,160 .

${ }^{6}$ Diary of the Soviet Ambassador Plenipotentiary to Lithuania S.Aleksandrovsky. N. 1. 2007 1926, Foreign Politics Archive of the Russian Federation [ FPARF], f. 04, inv. 27, F. 185 , P. 90, S.1. 
arrival in Kaunas, Aleksandrovsky set to work with vigour. He immediately made the acquaintance of the established relationships not only with the ambassadors from other countries, accredited in Kaunas, and Lithuanian politicians, but also with various Lithuanian businessmen, the cultural and scholarly community workers, local and foreign journalists. Permanent relations with the people from different social strata made it possible for him to obtain the most up-to-date information and be in the focus of the developments in Kaunas. During his stay in Kaunas Aleksandrovsky studied and got closely familiar with the aspirations of the Lithuanian society as well as the problems of domestic and international life. For instance, in his report to Moscow on November 17, 1925 he drew attention to Lithuanian society's particular concern over the Vilnius issue. The diplomat stressed that every Lithuanian politician who ever tried "to reconcile with Poland without Vilnius, was crushed" therefore presently, after the Locarno Conference, when Poland's international position had weakened, the Lithuanian government would certainly not dare to negotiate with Poland without Vilnius ${ }^{7}$. On the other hand, Aleksandrovsky also realized the fact that the Lithuanian statesmen viewed rapprochement with Poland as a natural thing, while co-operation with the USSR was only regarded as a necessity arising from the Lithuanian-Polish conflict. Bronius Kazys Balutis had repeatedly declared to the Soviet envoy that, should Poland understand its own interests and leave Lithuania with at least minimal guarantees for its independence, he personally would only be for Lithuania's agreement with Poland ${ }^{8}$. Balutis continued by saying that in the question of guarantees, trust, something which Lithuania did not feel where Poland was concerned, was especially important, so no government dares to negotiate with Poland over "a whole complex of issues". Were we able, we would gladly sit down at the table with the Poles and review all matters of dispute, but we cannot do this without rejecting our own needs, therefore by the treaty with the Soviets we want to insure ourselves against Poland ${ }^{9}$. Similar, only perhaps less explicitly stated, stances in dealing with the Soviet ambassador were also held by other Lithuanian politicians, such as Juozas Purickis, Leonas Bistras, Mykolas Krupavičius, Mykolas Sleževičius, J.Vailokaitis.

${ }^{7}$ Report 67 of Aleksandrovsky dated 17111925 to Semion Aralov, member of the College of the Foreign Affairs People's Commissariat [ FAPC], ibid., P. 85, S. 33.

${ }^{8}$ Diary of the USSR Ambassador Plenipotentiary to Lithuania S.Aleksandrovsky. N. 12. 192508 28,- Ibid., B. 90, P. 47.

${ }^{9}$ Ibid., 48. It is worth noting that Aleksandrovsky regarded the political and diplomatic abilities of B.K. Balutis, M. Krupavičius, V. Sidzikauskas and Juozas Vailokaitis. Seriously characterizing Balutis, Aleksandrovsky pointed out that "Balutis was ten times more witty and cunning than V. Černeckis, and despite his sometimes being very open, it is not so easy to deal with him". Vailokaitis was characterized to Moscow as a "clever, strongwilled person of character". Krupavičius as a "self-confident, temperamental and elegant" man. Sidzikauskas was described as a "very serious man from the upper strata, making big politics". Among the Populists and Social Democrats he only mentioned M. Sleževičius, as a "more interesting figure", worth establishing closer contact with. 
Having assessed Lithuanian political tendencies and actual circumstances, on November 10, 1925 Aleksandrovsky proposed that Moscow should support Kaunas and try to make Lithuania a bridge rather than a barrier on the Soviet Union's road to Europe ${ }^{10}$. At the same time he presented a question - proposal to the board of the USSR Foreign Affairs People's Commissariat (FAPC): how were the Soviet- Polish relations being drafted and were there any prospects of reviewing the treaty of Riga. The ambassador wrote: "I am afraid to look like a fantasizer, but I am constantly worried by the thought that the time has come to essentially transform the map of the Vilnius Corridor and reach common boundaries with Lithuania: for example, to follow to the Dvina as far as the city of Dünaburg. I am taking the risk of asking these questions and will you please inform me whether or not you consider the latter question about re-drawing the map worth discussion? If so, I will gladly work in this direction and give information regarding the results, but I would like to hear your speculations considering the prospects for our relationship with Poland as this point is of crucial importance to our links with Lithuania"11. A week later, on November 17, 1925 Aleksandrovsky made an unambiguous hint to Aralov that Locarno had changed the situation considerably, and the Soviet policies with regard to Poland and Baltic States had to be corrected introducing essential improvements ${ }^{12}$. First and foremost, in respect to Lithuania, the diplomat categorically denounced Moscow's suspicions that allegedly the wish of Lithuania to establish closer contacts with the USSR was "the hand of England". Aleksandrovsky stressed that, on the contrary, Kaunas' policies are directed specifically against London which is pressing the Lithuanians to yield to the Poles; and the wish of Lithuania to maintain tension between Moscow and Warsaw follows not from London, but from Kaunas itself which is trying in this way to find itself an ally against Poland ${ }^{13}$. Therefore Moscow is unable to decline the political and economic rapprochement between the two countries proposed by the Christian Democrats even if it considers rapprochement with Poland to be its priority. At the same time the ambassador presented the FAPK with a programme for developing the relationship of Lithuania and the USSR. This programme envisages eight points:

1) to provide the Lithuanian industry with as many orders as it is capable of fulfilling,

2) to vigorously monopolize the Lithuanian market with Soviet commodities, above all oil products and coal,

3 ) to develop the programme of mutual credit in such a way the Lithuanian economy would feel its obvious advantages,

4) to grant Lithuania a financial loan,

${ }^{10}$ Report 64 of Aleksandrovsky dated 10111925 to Aralov, ibid., P. 85, 15.

${ }^{11}$ Ibid., 48.

${ }^{12}$ Report 67 of Aleksandrovsky dated 17111925 to Aralov, ibid., 26.

${ }^{13}$ Ibid., 38. 
5) to ask Georgij Chicherin during his visit to Kaunas to sign a letter of intent, as suggested by Mečislovas Reinys, corcerning the development of commercial and political relations between the countries,

6) seeking to bring the latter point into effect, to take the initiative from the Lithuanians and draft the intentions protocol in Moscow,

7) to take the initiative over the conclusion of a political treaty with Lithuania and to sign the pact before the election to the Third Seim is held. To use a political agreement with Lithuania for opposition's consolidation or political discredit of the ChristianDemocrats,

8) to establish useful contacts with the opposition immediately and support it in every possible way ${ }^{14}$.

The latter two points, according to Aleksandrovsky's scheme, should expand directly Moscow's measures designed for both the domestic and foreign policies of Lithuania. Commenting on the "eightpoint programme" the ambassador indicated on November 20 that Moscow should provide an opportunity the Christian-Democratic government to feel the "taste of agreement with us, later it will become even more dependent on us, and we will be able to exert pressure on it by either abolishing or temporarily withdrawing our orders before the election"15. In addition, before receiving any response from the Kremlin to his first initiative over the "drawing of the map", the envoy was writing again on November 20: "I would also suggest we review the 1920 borders. I keep thinking of reviewing the Treaty of Riga, our access to the Dvina and the Latvian rear as well as a corridor and common border with Lithuania ${ }^{16}$.

However, during late 1925 and the first half of 1926 Aleksandrovsky's initiative seemed to provoke no response in Moscow. The Kremlin continued to cherish hopes primarily for improving its relations with Poland, and trying to use its dialogue with Lithuania as a means of softening Warsaw's position. Moscow's eagerness to reach an agreement with Poland was demonstrated by an instruction letter of the USSR people's commissar of foreign affairs Chicherin to Aleksandrovsky, written on May 2, 1926. Evaluating Lithuanian's international standing and its position in the talks with Moscow, the USSR people's commissar of foreign affairs wrote: "If nothing changes in the international world and the situation remains the same forever, the Lithuanian view, namely that even without a non-aggression treaty the USSR will not attack Lithuania or aid its enemies, is correct. But one should not forget that anything in the world can become bargaining counter conspiracy, and something that connects us

${ }^{14}$ Ibid., 36-37.

${ }^{15}$ Report 68 of the USSR Ambassador Plenipotentiary to Lithuania S.Aleksandrovsky of 19251120 to the Member of the Board of FAPC S. Aralov, ibid., 44.

${ }^{16}$ Ibid., 45 . 
by the treaty, requires us to decline to bargain. My first meeting with de Monzié ${ }^{17}$ took place in Berlin in 1922 after his return from Klaipeda where he had met Petisné. Our first meeting and talks were highly significant and created a number of perspectives which subsequently were put into effect in our relationships with France. One of the key leitmotifs of de Monzié's speech was that he denied the usefulness of the existence of the Lithuanian state and drew a bright picture of Franco-Russian, Russo-French rapprochement. However, one obstacle is Lithuania which the French politicians defined as "a misunderstanding, a perfect mess" that had to be eliminated as soon as possible". Thus Chicherin concludes that "when one of the leaders of the French Left sought to establish links with us", he mentioned the elimination of Lithuanian statehood, as the key means of rapprochement. Therefore one should not take only the official statements of Aristide Briand and Philipe Berthelot, into consideration since the true tendencies of politics are often hidden in unofficial statements ${ }^{18}$.

Chicherin's second meeting with de Monzié was held near Lausanne, unbeknownst to the official French delegation. De Monzié again depicted rosy prospects for Franco-Russian relations and attempted to prove how the existence of the Lithuanian state was harmful and unnecessary. Chicherin went on by stressing that what had happened yesterday might also happen tomorrow. One should not neglect the possibility of a radical change in the policy towards rapprochement with France and an agreement with the USSR. In Poland, the Foreign Minister Aleksander Skrzyński could be replaced by a much bolder politician, who in 1926 or 1927, would offer us a "general agreement on all matters, including Poland's official rejection of her Baltic claims with the following bargain: Bessarabia and Galicia in exchange for Lithuania. I do not speak here of what our answer is going to be, yet the possibility of some proposal from the Franco-Polish side to give us a big compensation for Lithuania is completely logical"19.

In July 1926, when Lithuanian-Soviet talks were getting stuck and Kaunas did not refrain from its previous demands over Vilnius and Klaipèda and Moscow was hesitating what to do next (to continue the dialogue with the Lithuanians or seek more effective measures of an agreement with Poland), Aleksandrovsky took the initiative again. He realized Lithuania's complicated international situation and economic difficulties required essential changes. Lithuania found it more and more difficult to maintain its former politicy of wait-and-see. Lithuania's collations with Germany and reservations of Western states regarding Lithuania were a clear sign that in order to avoid

${ }^{17}$ Anatolé de Monzié - one of the leaders of the French Radical-Socialist party. Gabriel Jean Petisné - a civil commissar of the administrative government of the Entente states (practically - of France) in the Territory of Klaipeda (1920-09 01 1923).

${ }^{18}$ Letter of Chicherin to Aleksandrovsky dated 0205 1926, ibid., f. 0151, inv. 13, F. 25 , c. $2661,39$.

${ }^{19}$ Ibid., 38. 
political isolation Kaunas had to choose between Poland and the Soviet Union. It was no secret to the Soviet diplomat that the "Soviet card" in the political and diplomatic game over Vilnius was crucial. This followed from the whole course of the talks. Both the ChristianDemocrats and later - Populist-Social Democrats raised practically the same demands and objectives. The former were even determined to enter into something similar to a military alliance with the USSR. It would be unfair to use this to accuse the Christian Democratic government of adventurism, as this measure was of a rather defensive character against possible Polish aggression and the last attempt to internationalize the problem of Vilnius. Should Kaunas fail to do this, it would have no other choice than to seek an honourable reconciliation with Warsaw. Such opinions as were held by Kaunas politicians were repeatedly conveyed to the ambassador by the leader of the Lithuanian Nationalist Union, Antanas Smetona, and Director of the Economics Department of the Lithuanian Ministry of Foreign Affairs, Juozas Purickis, the secretary of the Lithuanian Embassy in the Soviet Union, Leopoldas Bagdonas ${ }^{20}$. Such prospects did not seem acceptable to Aleksandrovsky. The heir of the Russian Empire's expansionist foreign politics and its follower, the Soviet Union, did not wish to lose its traditional spheres of influence in the Baltic, which it had established in the 18th century. This did not correspond to the superpower interests of Russian (USSR) foreign policy which was disguised under the rhetoric of revolutionary "more progressive formation" and "sovietization".

In the middle of July 1926 Aleksandrovsky presented Moscow with an extensive report on the problems of Lithuanian and Polish domestic affairs and certain tendencies of the Western politics. First of all, the diplomat noted that the results of the Lithuano-Soviet negotiations over a non-aggression treaty would not become a mere episode in the history of the countries but would determine the LithuanoRussian mutual relations for many years to come. Furthermore, the ambassador believed that the results of negotiations with Lithuania would also be significant for Soviet relations with the other borderlands (Latvia, Estonia, Finland) and for Moscow's possibilities to expand its influence in the region in general ${ }^{21}$. Hence, he insisted upon paying extraordinary attention to the talks with Kaunas. As if countering the opinions expressed in Chicherin's letter of May 2, 1926, Aleksandrovsky proposed his own version concerning the prospects of the USSR's relations with Poland and Lithuania. He supported the opinion of the USSR People's Foreign commissar that coming to terms with Poland and France was incomparably more important to the Soviet Union than dealing with Lithuania and agreed that under certain circumstances it would be possible to negotiate with Warsaw c. 85,85 .

${ }^{20}$ Report 72 of Aleksandrovsky dated 13071926 to Aralov, ibid., f. 04, inv. 27, F. 185 ,

${ }^{21}$ Report 121 of Aleksandrovsky dated 20111925 to Aralov, ibid., F. 186, c. 102, 1. 
over the fate of Lithuania. The primary demand would be that in return for "ceding" Lithuania to Poland, the Polish-Rumanian mutual assistance treaty would be rescinded, and Poland would not meddle with the Soviet relations with Rumania and the solution of the Bessarabian issue, that it would renounce "in perpetuity" all claims to the Baltic, reject ideas of federalism with the Ukraine and Belorussia, refrain from expansion to Kiev and Minsk, also that it would accordingly review the Treaty of Riga of March 18, 192122. In effect Aleksandrovsky was proposing the following model for a Russo-Polish agreement: for the ceding of Lithuania to Poland the USSR was getting a free hand in the Baltic states and in relations with Rumania, and for the Soviet benefit Warsaw rejects her claims to Western Belorussia and the Ukraine. But Aleksandrovsky also claimed that even if these concessions had been obtained it was scarcely credible that RussoPolish antagonism would be obliterated, it would just be somewhat modified and "pushed underground". This process could last for years until new conflicts broke out. Therefore the Russian diplomat raised a question of principle to his government: was a long-term settlement of relations with "bourgeois" Poland at all possible?23 Basing his arguments broadly on historical parallells, the envoy pointed out that the historically established rivalry between Poland and Russia and economic competition were inevitable, especially after Józef Piłsudski had come to power. Piłsudski, he alleged, would "never forget his dreams about Kiev and Minsk" and try to justify his unconstitutional authority by looking for a way out in foreign politics and common national interests such as the development of "Greater Poland", linked by federal ties with Lithuania, Belorussia and the Ukraine ${ }^{24}$. The diplomat continues to analyse that Poland would become stronger by annexing Lithuania, and would immediately demand Kiev or Minsk. Therefore it was necessary to consider when and under what circumstances a clash with Poland would occur, instead of drafting a general agreement with Warsaw or thinking of a long-term peace with this country $^{25}$. The Kremlin's current task should be to weaken Poland's ambitions and make its life so difficult that a conflict with it would be delayed until it became "a force that can be disregarded".

Another point to which the Soviet envoy drew the attention of the FAPC board was Soviet-German relations. The diplomat doubted the sincerity of Berlin and the long-term effectiveness of the German-Soviet non-aggression and neutrality pact signed on April, 24,1926 . He maintained that the Germans were allegedly playing a double political game whose eventual aim was to destroy Poland by the Soviet hands, so that later the same could be done to Russia itself. Therefore, having assessed the political circumstances developing in

22Ibid., 3.

${ }^{23}$ Ibid., 2.

${ }^{24}$ Ibid.

${ }^{25}$ Ibid. 
Europe after Locarno, the ambassador suggested Moscow should watch Germany very closely. The latter was recovering too quickly, and seeking to dominate European politics once more. Such conclusions on Aleksandrovsky's part must have been prompted by the fact that in the course of the German-Soviet political dialogue in 19241926 Berlin had repeatedly emphasized to Moscow that it did not accept its eastern borders and would seek to push Poland back into its ethnographic boundaries. Drawing a parallell between the position of Berlin with the question that at the same time was being unofficially but vividly discussed in Europe's diplomatic circles about the possibilities of returning Gdańsk and the so-called "Polish Corridor" to Germany, and by way of compensation granting Poland access to the Baltic Sea via Klaipeda and Lithuania, the Russian envoy arrived at the conclusion that in the coming partition of Eastern Europe, the Soviet Union would be able to stand on the sidelines. He put forward an idea that in order to reclaim Danzig and the Corridor, Germany might formulate the following plan: it allows Poland to occupy Lithuania and the Klaipeda Region (Memelland), making a "friendly" suggestion to the Soviets to occupy Latvia and Estonia. Aleksandrovsky speculates further that in this way, by exchanging Gdańsk for Klaipèda, Germany would not only recover Gdańsk and the Polish Corridor but would soon reclaim Klaipèda from Poland as well. Under pressure of circumstances, the Soviet Union, the ambassador wrote, would hardly disagree with this suggestion from Berlin ${ }^{26}$. The Soviet diplomat's logic was simple: in this way Germany would recover all "its historic lands, and Russia (the USSR) would regain her "window on Europe". Of course, the ambassador admitted at the same time that this was only a remote possibility and that the further turn of events would depend on many different factors. Meanwhile, he proposed that Moscow should increase the wedge between Lithuania and Poland by all means, and "break" the Baltic front on the Lithuanian strip"

On the other hand, it is a typical and important thing too that Chicherin's information and Aleksandrovsky's speculations are in keeping with certain political scenarios envisaged by western states as recorded in historical sources or historiography. As the Polish historian Henryk Korczyk points out, in the memoirs of the British ambassador to Germany, Lord Edgar Vicent d'Abernon, the idea of Poland exchanging Gdańsk and the Corridor for Klaipedda and Lithuania dates back to March 15,1925 ${ }^{28}$. According to the same author, the Quai d'Orsay Secretary General, Berthelot, had envisaged this prospect in May $1925^{29}$. Late in June or early July 1925, the Lithuanian

${ }^{26}$ Ibid., 6.

${ }^{27}$ Report of Aleksandrovsky dated 21071926 (extension of the report of 19260713 ) to Aralov, ibid., 20.

${ }^{28}$ H. Korczyk, Przyjęcie Niemec i Polski do Rady Ligi Narodów w 1926 roku, WrocławWarszaw-Kraków-Łódz, 1986, 340.

${ }^{29}$ Ibid., 20. 
ambassador to the Soviet Union, Jurgis Baltrušaitis, got information about the ideas circulating in London and Paris ${ }^{30}$. For the sake of objectiveness, it has to be noted that the Lithuanian diplomat maintained very good relations with the English and French diplomats in Moscow, and he also had close links with Western capitals. For this reason, the Soviets even suspected him of co-operation with the intelligence services of the Western states. Late in August the same year the existence of these plans was mentioned to Aleksandrovsky by Balutis, Director of the Political Department of the Lithuanian Ministry of Foreign Affairs, who stressed that if they were put into effect this would "mean the destruction of Lithuania as an independent state"31. In mid-October the Latvian ambassador to Lithuania, Antons Balodis, asked Aleksandrovsky what exactly the Russians knew of the "Polish idea to cede the Liepaja-Memel corridor to Poland". In the Latvian diplomat's opinion, bearing in mind that the changing of German borders would start with Danzig, such plans were quite feasible ${ }^{32}$.

In June 1926 the tactical changes in Berlin's foreign policy, aimed at reviewing Germany's eastern borders, were made known in Warsaw by the Polish minister extraordinary and plenipotentiary to Germany, Kazimierz Olszowski. He reported that an initiative had been developed by the Auswärtiges Amt, according to which the revision of the Polish-German border could be brought about with or without paying territorial compensation ${ }^{33}$. This compensation could take the form of Klaipeda and Lithuania. On August 13, 1926, information about the discussion of these plans in Europe was passed to Kaunas by the Lithuanian ambassador to Germany Vaclovas Sidzikauskas ${ }^{34}$. The wish of certain French politicians to solve the Polish-German territorial disputes at the expense of Lithuania has also been discussed by the American historian Joseph Korbel ${ }^{35}$. The general context is successfully complemented also by the comment cited by Zenonas Ivinskis from the German document collection, Akten zur Deutschen Auswärtigen Politik 1918-1945. According to this source, in the autumn of 1926, in response to the Lithuanian minister's demand for the restoration of Lithuania's violated rights to Vilnius, the assistant director of the Political-Commercial Department of the French Ministry of Foreign Affairs and envoy Seydoux declared straightforwardly: "Be glad that you are allowed to live at all and do not talk of

${ }^{30}$ Letter No.20255 of Aralov dated 01071925 to the USSR Ambassador Plenipotentiary to Lithuania, I. Lorents, - FPARF, F. 04, inv. 27, F. 185, P. 86, 37.

${ }^{31}$ Diary of Aleksandrovsky dated 28081925 . No.12, ibid., P.90, 46.

${ }^{32}$ Diary of the USSR ambassador Plenipotentiary to Lithuania Aleksandrovsky No. 27, 19251023 , ibid., 87.

${ }^{33}$ H. Korczyk, op. cit., 340.

${ }^{34}$ Report of the Lithuanian Ambassador to Germany, V.Sidzikauskas dated 13081926 to the Lithuanian Prime Minister and Minister of Foreign Affairs M. Sleževičius, LCVA, f. 383 , inv.7, P.625, 119.

${ }^{35}$ J. Korbel, op. cit., 214. 
any demands. Unless you stop playing the role of the violators of peace in Europe, one of these days we will have to deprive you completely of such opportunities"36. A number of other facts are worth attention and relevant to the present study. On June 10,1926 the British government passed a decision not to undertake any action, should the political status of the Baltic countries change ${ }^{37}$. On October 7, 1926, commenting on Polono-German relations, the British Foreign Secretary Austin Chamberlain mentioned inter alia: "After all I am not saying that the decisions of Versailles will be valid forever or that they would necessarily have to be valid. I am only noting that Germany has solemnly pledged not to use war as a means to substitute them. /However/, if eventually this has to be changed to an agreement, Germany has to alter its entire attitude to Poland. Being an optimist, I sometimes allow myself to believe that as time goes by, it will understand that" 38 . On October 8, 1926 the French-language Messager Polonais in Warsaw published an article which categorically denied the statements, made by the press and some politicians that Warsaw had discussed "some kind of agreement" and that Poland would be reluctant to accept the ceding of Gdańsk and the Corridor to Germany in exchange for respective compensation ${ }^{39}$. The article immediately attracted the attention of the English ambassador to Poland, Sir W. Max Muller who on the very same day met the Polish Foreign Minister August Zaleski. The latter declared that the Messager article had been written at his request, as the Polish government did not wish to leave the slightest doubt about its attitude and wished to block the way to any further speculations of a similar sort ${ }^{40}$. All this shows that Poland had serious reasons for a public expression of its position. The Polish commitment was communicated to London by Muller without delay.

Without investigating who was the author of the idea of territorial exchanges between Poland and Germany (although chronologically it may have been Lord Vincent d'Arbernon), a question arose as to what cause of reasoning and action had inspirited the development and discussion of such a plan in the mid 1920s. We believe that an answer to this question can be provided by the answers to several other questions: (a) did the authors of the Versailles Peace Treaty, which defined the diplomatic order and state boundaries in post-war Europe, believe in the durability of the Polish Corridor? (b) why did

${ }^{36}$ Z. Ivinskis, Lietuvos ir Sovietų Sajungos santykių dvidešimtmetis 1919-1939. Reikšmingieji etapai šaltinių šviesoje, Aidai, 8, 1969, P. 347.

${ }^{37}$ Z. Butkus, Lietuvos ir Latvijos santykiai 1919-1929 metais, Vilnius, 1993, 100.

${ }^{38}$ Report 52 of the British Ambassador to Poland, Sir W.Max Muller, dated 08101926 to the Foreign Secretary, A. Chamberlain, - Documents on British Foreign Policy 1919. 1939. The Termination of Military Control in Germany. Middle Eastern and American Questions 1926-1927. Series IA, Vol.2, London, 1968, 428.

${ }^{39}$ Ibid., 427.

${ }^{40}$ Ibid., 428. 
Article 99 separate the Territory of Klaipeda from Germany and place it under temporary administration by the Entente states?

It is no secret that the idea of an expanded Poland, ruling vast territories, was as unacceptable to London, as it was to Berlin and Moscow. Therefore the problem of the Polish frontiers would have to be sorted out sooner or later. As pointed out by the member of the Lithuanian delegation at the Versailles Peace Conference, Balutis, when "the authors of the Versailles Pact, drafted Article 99, they already had in mind the possibility of providing Poland with an exit to the sea through Klaipeda. The Klaipeda Region had been separated from Germany not for the sake of ceding it to Lithuania, but in order to provide a back up should the Polish Corridor the fail" 41 . Thus a balance of forces was meant to be established in Europe for the time being. However, the protracted normalization of the terms between Germany and the Entente States corrected those calculations. As Lithuania consolidated and obtained international recognition, early in 1923 it managed to annex Klaipeda, granting it the rights of autonomy. As the crisis in the Ruhr region deepened, the territorial problems of Germany and Poland were not a policy priority for the Entente powers. The problem, however, was only set aside temporarily. The agreements of Locarno, the consolidation and political tendencies of Germany as well as Britain's efforts to integrate Germany into the West European security system and peacefully settle the Polish-German territorial dispute raised this problem again. An interesting interpretation of the international situation that had developed around the Polish-German knot during 1925-1926 and the ways of unravelling it and solving the Lithuanian situation was offered by Korczyk. This historian emphasized: Germany was capable of recovering the Corridor with the Soviet aid only in the case of a conflict between Poland and USSR, but here France would have intervened. The exchange of the corridor for Lithuania would have provoked a hostile reaction from the Soviets, who had a negative approach towards the Lithuanian-Polish union and Poland's consolidation, as this was in accordance with their interests. Germany was also unable to reclaim the corridor with British help, since relations between the USSR and Great Britain did not allow the latter to follow anti-Polish policies. Therefore, the only possibility for Berlin to achieve its goals was the French aid, which it could expect, should relations between Berlin and Paris acquire a more positive turn. On these grounds France tended to agree that in return for ceding the Corridor to Germany, Poland would take control of Lithuania. The only possibility to carry out such a plan was a Polish putsch in Lithuania, but in such a case the interests of Germany and Russia would clash as well ${ }^{42}$. 90,46

${ }^{41}$ Diary No.12 of Aleksandrovsky dated 2808 1925, FPARF, f. 04, inv. 27, F. 185, P. ${ }^{42}$ H. Korczyk, op. cit., 342. 
The Eastern European political scenario described above did not become a reality. Korczyk believed firmly that this was because Warsaw had declined to play the game. The Polish minister of foreign affairs had declared to the German secretary of state, Karl Theodor Conrad von Schubert: "never" Berlin for the normalization of their relations by ceding its own territories. Muller's report to the British Ministry of Foreign Affairs, maintained above, also speaks in Zaleski's favour. Agreeing with the conclusion of the Polish historian, we should also note that there were some other important reasons that obstructed the realization of the projects discussed. On the other hand, they were political and diplomatic efforts of the Lithuanian government to strengthen its international situation. It is also doubtful that Germany would have agreed to exchange one part of "its own" territory - Gdańsk and the Corridor) for another - Memel (Klaipeda). This presumption is partly confirmed by Korbe ${ }^{44}$ and the report of Sidzikauskas from Berlin ${ }^{45}$. After all, the Soviet Union was also planning to get considerable compensation for Lithuania, which could hardly have satisfied the parties concerned. Apart from that, it is necessary to agree with the conclusion of the secretary of the Lithuanian embassy to Germany, Stasys Lozoraitis, that should the sovereignty of Lithuania be disturbed, "the most serious problems" could arise in the Baltic, and their consequences could hardly be predicted ${ }^{46}$. Most probably, this argument, too, had figured in the heads of the initiators of this idea. Therefore the further process of political history was determined both by the subjective opinions of some or other politicians and the objective interests of different states.

${ }^{43}$ Ibid.

44J. Korbel, op. cit., 214.

${ }^{45}$ Report of Sidzikauskas dated 13081926 to the Lithuanian Prime Minister and Minister of Foreign Affairs Sleževičius, LCVA, f. 383, ap.7, P.265, 1. 119.

${ }^{46}$ Report of Lozoraitis dated 06101926 to the Director of the Political Department of the Lithuanian MFA, B.K. Balutis, ibid.,14. 